\title{
Internet Usage and Economic Growth: The Case of Mexico
}

\author{
Yu Hsing ${ }^{*}$, Yun-Chen Morgan, Antoinette S. Phillips, \& Carl Phillips \\ College of Business, Southeastern Louisiana University, Hammond, LA 70402, USA
}

\begin{abstract}
This paper finds that more internet users as a percentage of total population promote economic growth in Mexico and that the impact exhibited a nonlinear relation and was greater in the initial stage of Internet adoption. In addition, less government budget deficit as a percent of GDP, a higher real stock price, real peso appreciation, a higher real crude oil price or a lower expected inflation rate would enhance economic growth.
\end{abstract}

Keywords: Internet usage; economic growth; fiscal policy; exchange rates; energy costs.

\section{Introduction}

The Internet has made significant changes in our society. The Internet helps increase knowledge spillover, which promotes economic growth (Romer, 1986, 1990). Workers use the Internet to find relevant information, search for potential clients, communicate with others, and make business transactions. Researchers rely on the Internet to find the data, the literature, and journal information. Consumers use the Internet to search for products and product information, engage in online purchase, and pay bills online. The Internet has greatly facilitated the transition from face-to-face teaching to remote teaching and learning during the recent pandemic crisis. Many of these activities tend to reduce the cost of doing businesses, enhance productivity, increase private spending, promote people's wellbeing, and increase national output.

The purpose of this paper is to examine the impact of Internet usage on national output for Mexico. Other relevant economic variables will be considered as well. This paper has several different aspects. First, a macroeconomic model including the IS function, the monetary policy reaction function and aggregate supply (AS) is formulated whereas several other studies (Choi and Yi, 2009; Niebel, 2018; Garcia, 2019) employ the growth equation (Solow, 1956) or the Cobb-Douglas production function in formulating theoretical models. Second, Internet usage is incorporated in the IS and AS functions, suggesting that the Internet is expected to facilitate or stimulate private spending, increase productivity, and reduce the production cost.

\section{Literature Survey}

Several recent articles have examined the impact of the Internet or high tech on economic growth and related subjects.

In reviewing the issues of Internet and E-commerce development in Mexico, Curry, Kennedy and Contreras (2001) indicate that Mexico needs to overcome some of the issues such as insufficient infrastructure, relatively high access costs, low credit card penetration making online purchases difficult, an untrustworthy postal service increasing the cost of courier delivery.

\footnotetext{
* Corresponding author.

E-mail address: yhsing@selu.edu (Yu Hsing)
} 
Using a sample of 53 countries including Mexico, Frehund and Weinhold $(2002,2004)$ find that the Internet promotes service and bilateral trade as the Internet causes fixed costs to decline and exports to rise.

Based on a sample of 53 host countries and 14 source countries, Choi (2003) studies the effect of the Internet on foreign direct investment (FDI) inflows. More Internet adoption tends to enhance labor productivity and attract FDI. His estimate using a gravity FDI equation shows that a $10 \%$ increase in Internet users in the host country leads to a $2 \%$ rise in FDI inflows.

Using the same data sample of 42 developed and developing countries during 1993-2001 (Arellano and Bond, 1991) with different methodologies, Papaioannou and Dimelis (2007) show that ICT has a stronger effect on labor productivity in the developed countries whereas Dimelis and Papaioannou (2010) find that ICT has a weaker effect in developed than developing countries.

Based on a sample of 60 countries during 1995-2002, Noh and Yoo (2008) report that Internet adoption and economic growth have a negative relationship in countries with relatively high degree of income inequality mainly due to the digital divide. Hence, income redistribution will reinforce the positive impact of the Internet on economic growth.

Choi and Yi (2009) examine the effect of the Internet on economic growth using a sample of 207 countries during 1991-2000. They specify that economic growth is a function of the Internet, the ratio of investment to GDP, the ratio of government spending to GDP, and the inflation rate. Several econometric techniques including the pooled OLS, the panel generalized method of moments (GMM), the random effect, the fixed effect, etc. are employed. They find that more Internet users promote economic growth.

Applying a modified gravity equation, Choi (2010) examines the effect of the Internet on service trade based on a sample of 151 countries over the period of 1990-2006. He specifies service trade as a function of the Internet, gross domestic product, total population, the ratio of M2 money to GDP, and a year dummy variable. Various econometric techniques are employed. He shows that if Internet users rise 10\%, service trade would increase from $0.23 \%$ to $0.42 \%$.

Applying the growth model and using a sample of 62 developed and developing countries during 2000-2006, Yousefi (2011) shows that Information and Communication Technology (ICT) affects economic growth in several income group countries differently and that ICT has a significant role in economic growth of upper-income and high-income groups and that ICT does not make contribution to economic growth for the lower-middle income group.

Using a sample of 45 developed and developing countries during 1994-2007, Dedrick, Kraemer and Shih (2013) reveal that ICT makes contribution to economic growth for both developed and developing countries and that the output elasticity is slightly less in upper-income developing countries than developed countries.

Najarzadeh, Rahimzadeh and Reed (2014) study the effect of the Internet on labor productivity for 108 countries during 1995-2010. They show that more Internet users tend to increase labor productivity due to more efficiency and cost saving in getting the information, communication and getting the work done.

Niebel (2018) compares the impact of information and communication technologies (ICT) on economic growth for 59 developed, emerging and developing countries during 1995-2010. Mexico is part of emerging countries. Based on the more comprehensive version, he finds that ICT has a positive impact on economic growth and differences among the three groups of countries are not significant. Specifically, the coefficient of ICT ranges from 0.049 to 0.073 for developed countries, from 0.057 to 0.071 for emerging countries, and from 0.067 to 0.103 for developing countries.

Garcia (2019) examines the effect of information and communication technologies (ICT) on national output in Mexico using a sample during 1990-2014. A Cobb-Douglas production function with the Slow-Swan growth model (1956) is applied. Employing the TSLS method, he finds that ICT has a positive impact on national output whereas the price of the Internet has a negative impact on national output.

\section{The Model}

The macroeconomic model includes the IS function, the monetary policy reaction function, and the AS function. In the IS function, aggregate expenditures are determined by the gross domestic product, government spending, government tax revenue, the real interest rate, the real stock price, the real effective exchange rate, and internet usage. 
In the monetary policy reaction function, the real interest rate is influenced by the inflation gap, the output gap, and the real effective exchange rate. In the aggregate supply function, the inflation rate is affected by the expected inflation rate, the output gap, the real effective exchange rate, the real energy cost and Internet usage. Assume that the target inflation rate and potential real GDP are constants in the short run. Solving for the three unknown endogenous variables, namely real GDP, the real interest rate and the inflation rate, we can find equilibrium real GDP as:

$$
\mathrm{Y}=w(\mathrm{IT}, \mathrm{DF}, \mathrm{SP}, \mathrm{EX}, \mathrm{EC}, \mathrm{EI})
$$

where

$\mathrm{Y}=$ equilibrium real gross domestic product (GDP),

IT = Internet users,

$\mathrm{DF}=$ government deficits,

$\mathrm{SP}=$ real stock prices,

$\mathrm{EX}=$ real effective exchange rate,

$\mathrm{EC}=$ real energy cost, and

$\mathrm{EI}=$ the expected inflation rate.

An analysis of the data reveals that the impact of Internet usage is greater in the initial stage and smaller in the later stage. Hence, to estimate potential changes in the slope and the intercept, an interactive binary variable and an intercept binary variable are included in the estimated equation:

$$
\mathrm{Y}=z(\mathrm{IT}, \mathrm{IT} x \mathrm{~B}, \mathrm{~B}, \mathrm{DF}, \mathrm{SP}, \mathrm{EX}, \mathrm{EC}, \mathrm{EI})
$$

where $\mathrm{B}=0$ before 2001 and $=1$ during 2001-2018.

The sign of IT should be positive as increased Internet usage tends to increase worker productivity, reduce the production cost, increase private spending, shifting aggregate supply to the right and aggregate demand to the right. The sign of IT x B tends to be negative, indicating that the impact of the later stage is smaller than the impact of the first stage. The sign of DF tends to be positive as expansionary fiscal policy would increase national output at least in the short run. The sign of SP tends to be positive because a higher real stock price increases household wealth, improve business financial condition, and increase private spending.

The sign of EX is unclear because real appreciation of the Mexican peso tends to reduce the cost of imported goods and shift aggregate supply to the right. On the other hand, real appreciation tends to hurt exports and shift aggregate demand to the left. The net impact is unclear. The sign of EC may be unclear because a higher energy cost would shift aggregate supply to the left and reduce equilibrium $\mathrm{Y}$ and because Mexico is an oil-exporting country. A higher real energy cost tends to encourage Mexico to produce and export more crude oil and increase national output. The sign of EI is negative as a higher expected inflation rate shifts aggregate supply to the left, raise the inflation rate and reduce equilibrium real GDP.

\section{Empirical Results}

The data were collected from the World Economic Outlook, the International Financial Statistics, and the World Bank. Real GDP is measured in billion pesos. Government budget deficit is measured as fiscal balance as a percent of GDP. The real stock price is an index with 2010 as the base year and adjusted for the consumer price index. An increase in the real effective exchange rate indicates real appreciation of the peso. The real energy cost is represented by the real crude oil price per barrel measured in the peso. Internet usage is represented by Internet users as a percent of total population.

An analysis of the data in Figure 1 shows that Internet users as a percent of total population was relatively small in the 1990s partly due to unavailability of Internet services. In 2002, it passed the 10\% level. By 2013, it reached 43.46\% level. In 2018, it rose to $65.77 \%$ of total population. Figure 2 describes movements in real GDP. Two major setbacks occurred due to the 1993-1994 peso crisis and the 2008-2009 global financial crisis. Figure 3 illustrates the relation 
between Internet usage and real GDP. The steep slope during 1991-2000 suggest that the impact of Internet usage on real GDP was greater during 1991-2000 than that during 2001-2018.

\section{INTERNET_USERS}

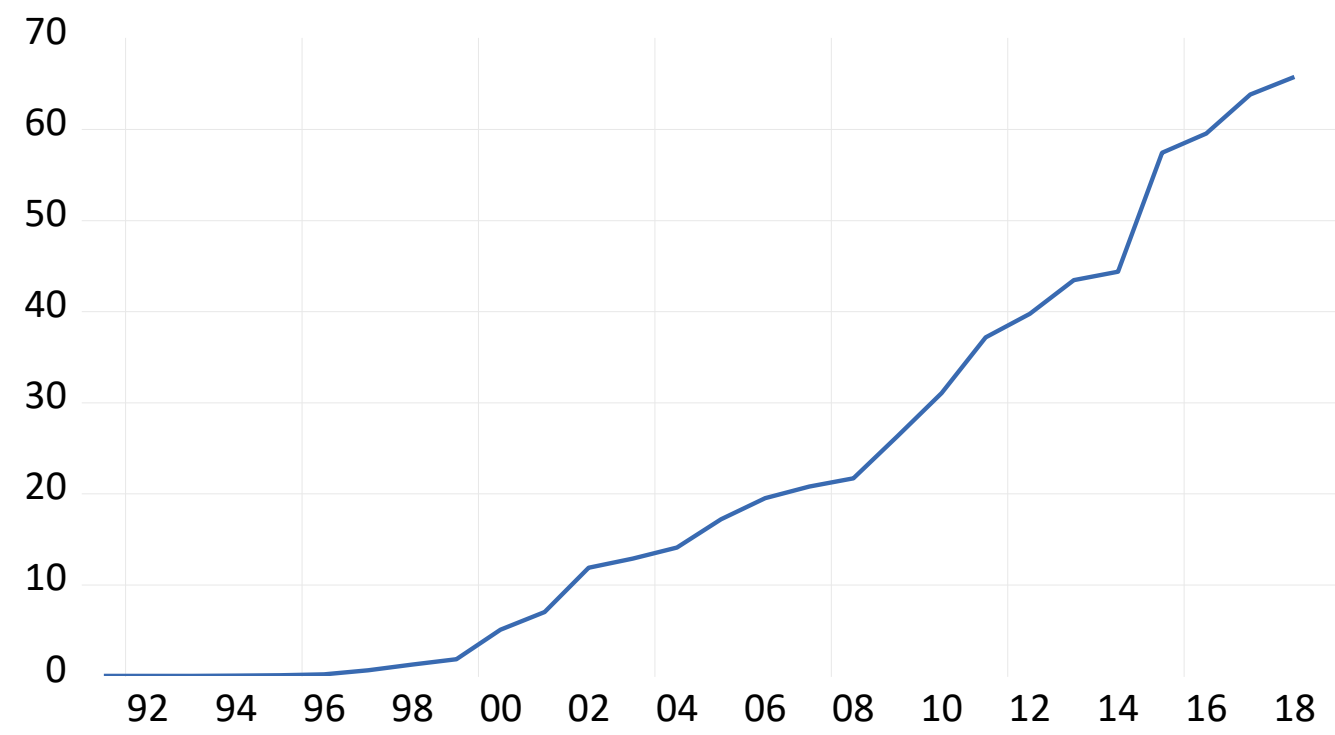

Fig. 1. Internet users as a percent of total population over time

\section{RGDP}

20,000

18,000

16,000

14,000

12,000

10,000

8,000

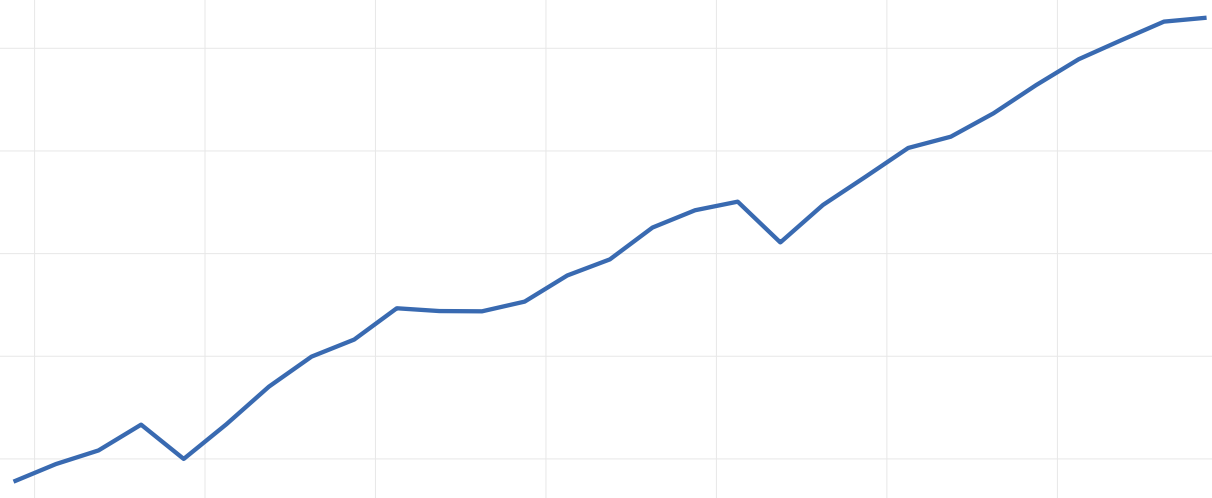

\section{$\begin{array}{llllllllllllll}92 & 94 & 96 & 98 & 00 & 02 & 04 & 06 & 08 & 10 & 12 & 14 & 16 & 18\end{array}$}

Fig. 2. Real gross domestic product (GDP) over time

The sample used in empirical work ranges from 1997 to 2018. The data for fiscal balance as a percent of GDP before 1997 and Internet users beyond 2018 are unavailable. Table 1 presents the estimated regression and related statistics. 
Potential autoregressive conditional heteroskedasticity has been corrected. As shown, approximately $98.36 \%$ change in real GDP can be explained by the eight right-hand side variables. All the coefficients are significant at the $1 \%$ level. Real GDP is positively associated with Internet usage, the real stock price, the real effective exchange rate and the real oil price and negatively influenced by the interactive binary variable, the intercept binary variable, fiscal balance as a percent of GDP, and the expected inflation rate.

Specifically, if Internet users as a percentage of population increases by 1 percentage point, real GDP would rise by 154.09 billion pesos during 1997-2000 and increase by 104.73 billion pesos during 2001-2018. In other words, using the mean value of real GDP during the sample period, a 1 percentage-point increase in Internet users as a percent of population would lead to an increase in real GDP by $1.12 \%$ during 1991-2000 and $0.76 \%$ during 2001-2018, respectively.

\section{0,000}

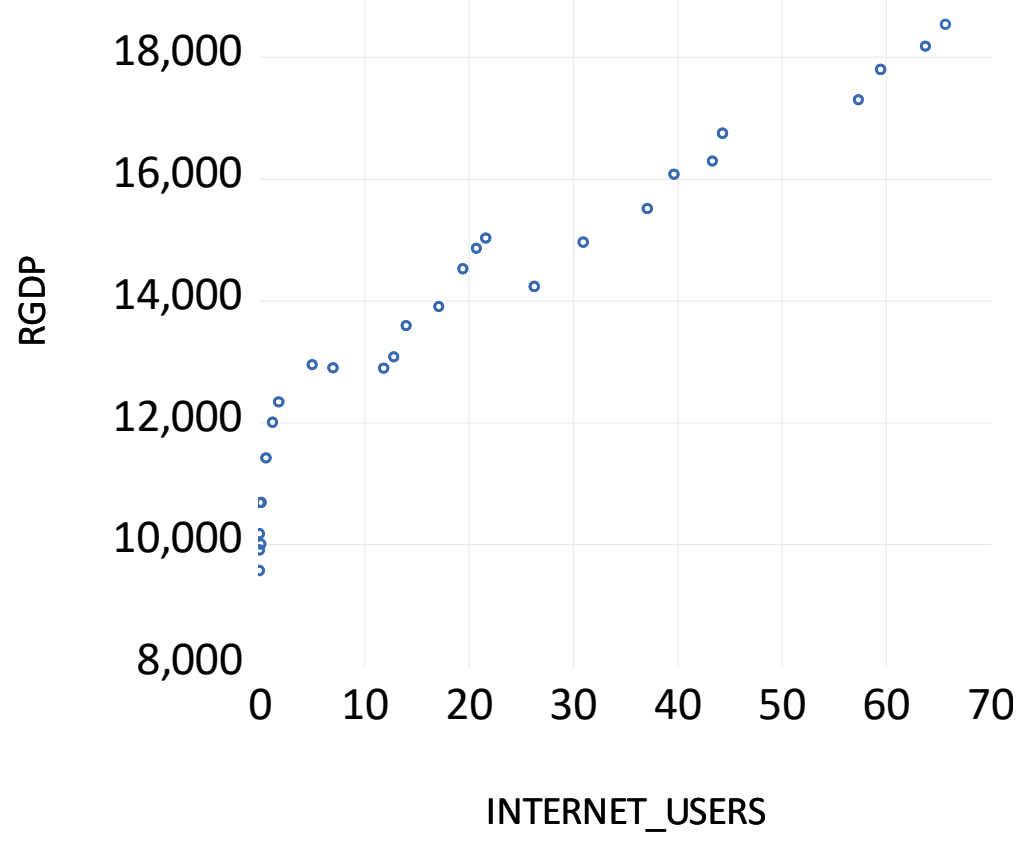

Fig. 3. Scatter diagram between real GDP (RGDP) and Internet users

In comparison, the positive effect of the Internet on economic growth found in this paper is consistent with the results reported by Choi and Yi (2009), Dedrick, Kraemer and Shih (2013), Niebel (2018) and Garcia (2019) but in contrast with the results found by Noh and Yoo (2008). In addition, this paper has an additional finding that the impact of Internet usage on economic growth had declined after 2000.

Expansionary fiscal policy has a negative effect on real GDP probably due to a larger crowding-out effect on private spending. When the real stock price rises by 1 unit, real GDP would increase by 9.20 billion pesos mainly due to the household wealth effect and the positive impact on business financial position. If the real effective exchange rate rises by 1unit, real GDP would rise by 18.41 billion pesos, suggesting that positive impacts of real appreciation of the peso such as less inflation pressure and more international capital inflows would outweigh its negative impacts such as less exports. The relatively small value of the positive coefficient for the real crude oil price may suggest that negative impacts of a higher crude oil price may cancel out positive impacts on crude oil production and national output. If the expected inflation rate rises 1 percentage point, real GDP would decline by 30.45 billion pesos. Therefore, the Bank of Mexico may need to lower inflation expectations to avoid its negative impact on national output. 
Table 1. Estimated regression of real GDP in Mexico

\begin{tabular}{lcc}
\hline Variable & Coefficient & Probability \\
\hline Intercept & 10617.15 & 0.0000 \\
Internet users & 154.0890 & 0.0000 \\
Internet users x binary variable & -49.3453 & 0.0000 \\
Binary variable & -1164.3330 & 0.0000 \\
Fiscal balance/GDP ratio & -210.4137 & 0.0000 \\
Real stock price & 9.2048 & 0.0000 \\
Real effective exchange rate & 18.4061 & 0.0000 \\
Real oil price & 0.1747 & 0.0000 \\
Expected inflation rate & -30.4467 & 0.0000 \\
R-squared & 0.9836 & 0.0000 \\
Sample period & $1997-2018$ & \\
Number of observations & 22 & \\
\hline Net In
\end{tabular}

Notes: Internet users are measured as the number of Internet users as a percent of total population.

The binary variable is equal to zero during 1997-2000 and one during 2001-2018.

\section{Summary and Conclusions}

This paper focuses on the impact of Internet usage on economic growth in Mexico. A macroeconomic model is specified to incorporate Internet usage in the IS and aggregate supply functions. The paper finds that the impact of Internet usage on national output varied during the sample period. The impact is larger during 1991-2000 and smaller during 2001-2018. In percent terms, when Internet users as a percent of population rise 1 percent, its impact on national output was $1.12 \%$ during 1991-2000 and $0.76 \%$ during 2001-2018. Other findings show that more government budget deficit and a higher expected inflation rate hurt national output whereas higher real stock prices, real appreciation of the peso and higher crude oil prices help raise national output.

There are some policy implications. The current Internet users/population ratio of $65.77 \%$ suggests that there is room for further expansion to areas where Internet services have not been covered. The negative impact of more government deficits on national output implies that fiscal prudence may need to be pursued. The government may need to monitor the peso exchange rate closely as real depreciation of the peso would generate a negative net impact on national output mainly because higher domestic inflation trigged by higher imported costs and international capital outflows. Further improvements in infrastructures with more broadband installation may be needed to increase the efficiency and effectiveness of the Internet.

\section{References}

Arellano, M., \& Bond, S. (1991). Some tests of specification for panel data: Monte Carlo evidence and an application to employment equations. The Review of Economic Studies, 58(2), pp. 277-297.

Choi, C. (2003). Does Internet stimulate foreign direct investment? Journal of Policy Modeling, 25, 319-326.

Choi, C. (2010). The effect of the internet on service trade. Economics Letters, 109, 102-104.

Choi, C., \& Yi, M. H. (2009). The effect of the internet on economic growth: Evidence from cross-country panel data. Economics Letters, 105, 39-41.

Curry, J., Kenney, M., \& Contreras, O. (2001). Internet and E-commerce Development in Mexico. Berkeley Roundtable on the International Economy, University of California, Berkeley.

Dedrick, J., Kraemer, K. L., \& Shih, E. (2013). Information technology and productivity in developed and developing countries. Journal of Management Information Systems, 30(1), pp. 97-122. 
Dimelis, S., \& Papaioannou, S. (2010). FDI and ICT effects on productivity growth: A comparative analysis of developing and developed countries. European Journal of Development Research, 22(1), pp. 79-96.

Frehund, C., \& Weinhold, D. (2002). The Internet and international trade in services. American Economic Review, 92(1), 236-240.

Frehund, C., \& Weinhold, D. (2004). The effect of the Internet on international trade, Journal of International Economics, 62, 171-189.

García, M. J. (2019). The impact of information and communication technologies on economic growth in Mexico. International Journal of Business and Social Research, 9(02), 11-22.

Najarzadeh, R., Rahimzadeh, F., \& Reed, M. (2014). Does the Internet increase labor productivity? Evidence from a cross-country dynamic panel. Journal of Policy Modeling, 36, 986-993

Niebel, T. (2018). ICT and economic growth-Comparing developing, emerging and developed countries. World Development, 104, 197-211.

Noh, Y. H., \& Yoo, K. (2008). Internet, inequality and growth. Journal of Policy Modeling, 30(6), 1005-1016.

Papaioannou, S., \& Dimelis, S. (2007). Information technology as a factor of economic development: Evidence from developed and developing countries. Economics of Innovation and New Technology, 16(3), pp. 179-194.

Romer, P. M. (1986). Increasing returns and long-run growth. Journal of Political Economy, 94, 1002-1037.

Romer, P. M. (1990). Endogenous technical change. Journal of Political Economy, 98 (5), S71-S101 Part 2.

Solow, R. M. (1956). A contribution to the theory of economic growth. Quarterly Journal of Economics, 70(1), 6594.

Yousefi, A. (2011). The Impact of Information and Communication Technology on Economic Growth: Evidence from Developed and Developing Countries. Economics of Innovation and New Technology, 20(6), pp. 581596. 